\title{
MODERNISASI PENDIDIKAN: POTRET DINAMIKA SOSIAL PENDIDIKAN PESANTREN DALAM NOVEL NEGERI 5 MENARA KARYA AHMAD FUADI
}

\section{MODERNIZATION OF EDUCATION: THE PORTRAYAL OF SOCIAL DYNAMICS AT ISLAMIC BOARDING SCHOOLS IN AHMAD FUADI'S NEGERI 5 MENARA}

\author{
Naeli Wardani ${ }^{1}$, Heru S.P. Saputra ${ }^{2} *$, Sunarti Mustamar ${ }^{3}$ \\ ${ }^{1}$ Alumni Fakultas Ilmu Budaya Universitas Jember \\ ${ }^{2,3}$ Fakultas Ilmu Budaya Universitas Jember \\ *Corresponding Author: herusp.saputra.fib@unej.ac.id \\ Informasi Artikel:
}

Dikirim: 7/2/2020; Direvisi: 10/5/2020; Diterima: 4/7/2020

\begin{abstract}
This research discusses the pesantren (Islamic boarding school) education system's reflection in the novel entitled Negeri 5 Menara. The research method used is qualitative in the sociology of literature approach. It is used to cover up the author's social context, literature as a reflection of society, and literature's social function. The study results in the author's social context show that author creativity is motivated by the author's experience and social construction of the author's ideology. In literature as a reflection of society, it described some similarities are found between Pondok Madani and Pondok Modern Darussalam Gontor (PMDG) in implementing a modern education system. It shows that the novel is a representation of social conditions. Modernity in the education system at the pesantren includes jasus [spy], the strict of time discipline, discipline in dress, mudhaharah (speech in three languages), memorization of Arabic vocabulary, use of foreign languages (Arabic and English), a system of admission with selection, and extracurricular activities. In the social function of literature, there are several responses from readers in assessing the novel Negeri 5 Menara's benefits. The author's contribution in giving a message to readers is focused on the function of socio-educationalism.
\end{abstract}

Keywords: author's ideology, modern, education, sociology of literature

\begin{abstract}
Abstrak
Penelitian ini bertujuan untuk mendiskusikan refleksi sistem pendidikan pesantren dalam novel Negeri 5 Menara karya Ahmad Fuadi. Metode penelitian yang digunakan adalah metode kualitatif dengan pendekatan sosiologi sastra, dengan cakupan konteks sosial pengarang, sastra sebagai cerminan masyarakat, dan fungsi sosial sastra. Hasil kajian dalam konteks sosial pengarang menunjukkan bahwa penciptaan novel Negeri 5 Menara dilatarbelakangi oleh pengalaman pengarang, sekaligus sebagai konstruksi social atas ideologi pengarang. Dalam sastra sebagai cerminan masyarakat, ditemukan beberapa kesamaan antara Pondok Madani dan Pondok Modern Darussalam Gontor (PMDG) dalam menerapkan sistem pendidikan yang modern. Hal tersebut menunjukkan bahwa novel menjadi reperesentasi kondisi sosial. Kemodernan dalam sistem pendidikan di pesantren tersebut meliputi jasus (mata-mata), penerapan kedisiplinan waktu, kedisiplinan berpakaian, mudhaharah (pidato menggunakan tiga bahasa), hapalan kosakata Arab, penggunaan bahasa asing (Arab dan Inggris), sistem penerimaan dengan seleksi, dan
\end{abstract}


Modernisasi Pendidikan: Potret Dinamika Sosial Pendidikan Pesantren dalam Novel Negeri 5 Menara Karya Ahmad Fuadi (Naeli Wardani, Heru S.P. Saputra, Sunarti Mustamar)

kegiatan ekstrakurikuler. Dalam fungsi sosial sastra, ditemukan beberapa tanggapan pembaca dalam menilai manfaat dari novel Negeri 5 Menara, dan kontribusi pengarang dalam memberikan amanat kepada pembaca, yang mengerucut pada fungsi sosial edukatif.

Kata kunci: ideologi pengarang, modern, pendidikan, pesantren, sosiologi satra

\section{PENDAHULUAN}

Kehidupan sosial santri memiliki perbedaan dengan kehidupan masyarakat di luar pondok pesantren, khususnya dalam hal pendidikan. Sebagai lembaga pendidikan Islam, pesantren memiliki tiga peran penting. Pertama, sebagai lembaga pendidikan yang menyelenggarakan pendidikan, baik formal maupun informal yang secara khusus mengajarkan tentang agama. Kedua, sebagai lembaga sosial yang menampung para santri dari berbagai lapisan masyarakat muslim tanpa membeda-bedakan tingkat ekonomi dan sosial orang tuanya. Ketiga, sebagai lembaga penyiaran agama (Suharto, 2018:43-44).

Di Indonesia, pesantren sudah menjadi lembaga pendidikan yang dikenal sejak zaman kolonial. Sejak munculnya pesantren, pendidikan pesantren bersistem salaf, yaitu sistem pendidikan yang lebih memfokuskan ajaran dalam mengkaji kitab kuning, rasa kekeluargaan, dan sistem penerimaan santri tanpa seleksi. Perubahan zaman membuat pesantren termotivasi dalam menciptakan pondok-pondok modern. Salah satu pelopornya, yaitu Pondok Modern Darussalam Gontor (PMDG). Perbedaan pesantren modern dengan salaf terletak pada sistem pembelajaran, penguasaan bahasa asing, cara membentuk pola disiplin, dan proses penerimaan santri (harus dengan seleksi).

Eksistensi pondok pesantren bukan hanya penting bagi masyarakat yang hendak mengenyam pendidikan yang dominan kurikulum agama tesebut, melainkan juga menjadi perhatian sekaligus inspirasi bagi pengarang. Tidak sedikit pengarang Indonesia yang tertarik dan kemudian mengangkat kisah-kisah dalam hidupan pesantren ke dalam karya sastra, sebagai upaya untuk menyuarakan nilai-nilai yang tumbuh dan berkembang dalam pesantren. Salah satu pengarang yang mengangkat dunia pesantren dalam novelnya adalah Ahmad Fuadi (2009), salah satunya adalah novel Negeri 5 Menara.

Novel Negeri 5 Menara karya Ahmad Fuadi merupakan novel yang mengangkat kisah berkaitan dengan kemodernan sistem pendidikan di PMDG. Dalam novel tersebut, Pondok Madani merupakan cerminan dari PMDG. Artinya, realitas sosial menjadi inspirasi dalam menciptakan karya sastra. Dengan demikian, terdapat relasi mimetis antara karya sastra dan realitas sosial.

Dalam konteks seperti itu, maka penting untuk dipahami keterkaitan antara karya sastra dan realitas sosial. Untuk itu, kerangka konseptual yang relevan untuk diterapkan dalam analisis adalah konsep sosiologi sastra. Swingewood (dalam Faruk, 2015:1) mendefinisikan sosiologi sebagai studi yang ilmiah dan objektif mengenai manusia dalam masyarakat, studi mengenai lembaga-lembaga dan proses-proses sosial. Sementara, sastra merupakan sebuah studi yang bersifat evaluatif, subjektif, dan imajinatif, namun kedua ilmu tersebut memiliki objek yang sama, yaitu manusia dalam masyarakat (Ratna, 2004:2).

Penelitian ini berupaya untuk memahami dimensi sosiologis, baik menyangkut sisi pengarang, karya sastra, maupun pembaca. Konsep teoretis yang dibangun sebagai pondasi untuk memaknai dimensi sosiologis tersebut adalah konsep sosiologi sastra. Konsep sosiologi 
sastra mengkonstruksi latar sosiologis pengarang, muatan nilai-nilai sosiologis karya sastra, dan konteks sosiologis pembaca (Damono, 1978; Junus, 1986; Saraswati, 2003; Escarpit, 2005).

Sosiologi sastra diterapkan dalam analisis novel tersebut agar dapat diketahui gambaran kehidupan sosial di pesantren, khususnya cara penerapan sistem pendidikan di Pondok Madani yang terkenal ketat dalam mendisiplinkan siswa, terutama yang berkaitan dengan pembagian waktu belajar. Meskipun demikian, sebelum masuk analisis sosiologi sastra, terlebih dahulu diawali analisis struktural dalam rangka untuk memahami kesatuan antarunsur yang membangun keutuhan dan totalitas karya sastra (Maslikatin, 2007).

\section{METODE}

Dalam mengkaji novel Negeri 5 Menara dengan teori sosiologi sastra, peneliti menggunakan metode penelitian kualitatif. Menurut Ratna (2004:47), metode kualitatif memberikan perhatian terhadap data alamiah, data dalam hubungannya dengan konteks keberadaannya. Penelitian kualitatif merupakan penelitian yang mengutamakan kedalaman penghayatan terhadap interaksi antarkonsep yang sedang dikaji secara empiris (Semi, 1990:9).

Implementasi dalam menganalisis novel Negeri 5 Menara karya Ahmad Fuadi, digunakan metode analisis deskriptif dengan menekankan pendekatan struktural dan sosiologi sastra. Analisis struktural dilakukan dengan mengidentifikasi dan memaknai keterjalinan unsur-unsur intrinsik. Sementara itu, penekanan pedekatan sosiologi sastra digunakan untuk menafsirkan konteks sosial, baik menyangkut pengarang, karya sastra, maupun pembaca.

Objek material penelitian ini adalah novel Negeri 5 Menara karya Ahmad Fuadi, informasi-informasi sosiologis di seputar pengarang, informasi-informasi sosiologis di seputar pembaca. Untuk mendapatkan data-data tekstual dari novel, diperlukan pembacaan yang cermat dan kritis sehingga dapat menemukan satuan analisis berupa kalimat atau paragraf yang memuat dimensi sosiologis dari karya terkait. Sementara itu, data yang terkait pengarang dan pembaca dapat ditelusuri dari dokumen-dokumen tertulis yang membahas dan relevan dengan lingkup sosiologis dari kedua sumber informasi tersebut.

\section{HASIL DAN PEMBAHASAN}

Dalam menganalisis novel Negeri 5 Menara, peneliti menggunakan kajian struktural untuk mengetahui keterkaitan antarunsur dan kajian sosiologi sastra untuk mengetahui keterkaitan karya sastra dengan kondisi sosial yang melatarbelakanginya. Unsur-unsur yang dibahas dalam kajian struktural mencakup keterjalinan antarunsur struktural, meliputi judul, tema, tokoh, konflik, dan latar. Adapun unsur-unsur yang dibahas dengan kajian sosioloi sastra, meliputi konteks sosial pengarang, sastra sebagai cerminan masyarakat, dan fungsi sosial sastra.

\section{Analisis Struktural}

Hasil kajian struktural terhadap novel Negeri 5 Menara menunjukkan bahwa masingmasing unsur struktural saling berkelindan dalam mendukung keterjalinan antarunsur. Unsurunsur tersebut meliputi unsur judul, tema, tokoh, konflik, dan latar. Sebagaiamana dijelaskan Jones (dalam Maslikatin, 2007:12), judul karangan dapat menunjukkan nama tokoh utama, 
alur waktu dalam cerita yang disusun secara kronologis, objek yang dikemukakan dalam cerita, menunjukkan keadaan atau suasana cerita, dan dapat menunjukkan beberapa pengertian, misalnya tempat dan suasana. Berdasarkan unsur-unsur yang dikemukakan Jones, judul novel Negeri 5 Menara karya Ahmad Fuadi menunjukkan beberapa pengertian, seperti tempat dan suasana. Hal tersebut dapat diketahui dari judul Negeri 5 Menara yang dalam novel menunjukkan negeri-negeri yang tersebar di dunia dan masing-masing memiliki menara. Kelima negeri tersebut merupakan negeri-negeri yang menjadi tempat impian Alif dan sahabat-sahabatnya dalam meraih cita-cita. Kelima negeri tersebut adalah Amerika, Eropa, Afrika, Asia, dan Indonesia.

Amerika sebagai benua impian Alif memiliki menara Monumen Washington yang terletak di Washington DC. Eropa, benua impian Raja memiliki menara Bigbang yang terletak di Inggris. Afrika sebagai benua impian Atang memiliki menara masjid Al-Azhar yang terletak di Kairo, Mesir. Asia sebagai benua impian Baso memiliki menara masjidil Haram yang terletak di Mekkah, Arab Saudi. Sementara, Said dan Dulmajid memilih Indonesia yang memiliki menara Monas yang terletak di Jakarta.

Konteks pemaknaan terhadap judul tersebut tidak dapat dilepaskan dari pembicaraan tentang tema. Sebagaimana diketahui, tema merupakan dasar cerita, gagasan dasar umum sebuah karya novel. Gagasan umum yang telah ditentukan oleh pengarang digunakan untuk mengembangkan cerita (Nurgiyantoro, 2005:70). Tema menjadi inti keseluruhan dari sebuah karya sastra, khususnya pada novel. Setiap pembaca memiliki gagasannya sendiri dalam menentukan tema. Nurgiyantoro (2005:82) membagi tema menjadi dua, yaitu tema mayor dan tema minor. Tema mayor mengacu pada tokoh utama, sedangkan tema minor mengacu pada tokoh tambahan. Tema mayor yang dimunculkan dalam novel Negeri 5 Menara, yaitu kesuksesan datang dari arah dan cara yang tidak terduga. Hal ini terkait dengan tindakan dan peristiwa yang dialami tokoh utama. Beberapa tema minor yang terdapat dalam novel Negeri 5 Menara, yaitu ada atau tidak adanya kesempatan akan diketahui setelah mencoba, usaha keras selalu mendatangkan hasil yang memuaskan, dan kewajiban berbakti kepada orang tua harus tetap dilaksanakan meskipun harus mengorbankan impian diri sendiri. Tema-tema minor tersebut mencerminkan perjalanan pengalaman dan hidup para tokoh bawahan.

Dalam konteks semacam itu, maka tema berkaitan langsung dengan tokoh dan perwatakannya. Sebagaiamana yang dijelaskan oleh Sudjiman (dalam Maslikatin, 2007:12), tokoh adalah individu rekaan yang mengalami peristiwa dan perlakuan dalam berbagai peristiwa cerita. Tokoh dalam karya sastra tidak hanya manusia, dapat juga binatang, dan benda-benda yang dibuat hidup oleh pengarang. Tokoh dibagi menjadi dua, yaitu tokoh utama (yang banyak berperan dalam cerita) dan tokoh bawahan (yang mendukung keberadaan tokoh utama). Setiap tokoh memiliki karakter yang berbeda sehingga menimbulkan pertentangan atau konflik yang membuat cerita semakin dramatik. Karakter atau perwatakan tersebut menunjuk pada sifat atau sikap yang dimiliki tokoh cerita. Wellek dan Warren (2014:266) membagi watak tokoh menjadi dua, yaitu watak bulat (round characterization) dan watak datar (flat characterization).

Tokoh Alif Fikri merupakan tokoh utama dalam novel Negeri 5 Menara. Sebagai tokoh sentral, Alif banyak mengalami konflik, banyak berinteraksi dengan tokoh lain, dan 
memiliki waktu penceritaan lebih banyak daripada tokoh lain. Keberadaan Alif sebagai tokoh utama didukung oleh hadirnya tokoh bawahan. Adapun tokoh bawahan yang lebih banyak mendukung keberadaan tokoh utama, yaitu Said Jufri, Dulmajid, Raja Lubis, Atang Yunus, dan Baso Salahuddin. Eksistensi tokoh yang berhubungan atau berinteraksi dengan tokoh lain berpotensi memunculkan persoalan atau konflik.

Konflik adalah sesuatu yang dramatik, mengacu pada pertarungan antara dua kekuatan yang seimbang dan menyiratkan adanya aksi dan aksi balasan. Tarigan (dalam Maslikatin, 2007:21) membagi konflik menjadi dua yaitu konflik fisik atau konflik eskternal dan konflik psikologis atau konflik internal. Konflik yang terjadi dalam novel Negeri 5 Menara dialami para tokoh, yaitu Alif, Amak, Randai, Dulmajid, Raja, Atang, dan Baso, Rajab, Ustaz Torik, Said, dan Pak Etek Gindo. Konflik fisik atau eksternal lebih dominan dibandingkan konflik batin atau internal. Dalam novel Negeri 5 Menara, konflik yang melibatkan antara manusia dan manusia terjadi antara Alif dan Amak. Konflik tersebut diawali oleh adanya perselisihan yang membuat Alif marah dan membanting pintu di depan orang tuanya. Dalam mewujudkan cita-cita masing-masing, tokoh-tokoh dalam novel Negeri 5 Menara mengalami konflik, baik konflik fisik seperti mendapatkan hukuman selama mencari ilmu, maupun konflik batin seperti meragukan suatu hal dan bingung terhadap kesuskesan di masa depan. Konflik fisik melibatkan Alif dengan tokoh-tokoh bawahan seperti, Amak, Rajab, dan Ustaz Torik. Konflik batin banyak dialami oleh Alif dan dipengaruhi oleh keberadaan tokoh tambahan, yaitu Randai, Amak, Pak Etek Gindo, dan Baso.

Tokoh dan konflik terkait berkelindan dengan latar yang menjadi bagian atau konteks dari perbuatan dan kejadian yang dialami tokoh. Sebagaimana diketahui, latar adalah tempat terjadinya peristiwa dalam cerita atau lingkungan yang mengelilingi pelaku. Latar menjadi warna lokal dan menggambarkan budaya yang ditunjukkan oleh pengarang dalam karyanya. Nurgiyantoro (2005:227) membagi latar menjadi tiga yang meliputi, latar tempat, latar waktu, dan latar sosial. Latar tempat dalam novel Negeri 5 Menara meliputi, Kampung Bayur, Pondok Madani, Bandung, Surabaya, London, dan Washington DC. Beberapa wilayah, baik di dalam maupun di luar negeri tersebut, menjadi gambaran lingkungan terjadinya peristiwa yang dialami para tokoh, sehingga kisah menjadi semakin terasa hidup.

Sementara itu, latar waktu dalam novel Negeri 5 Menara tidak disebutkan dengan jelas, tetapi berdasarkan peristiwa yang terjadi, latar waktu diperkirakan berlangsung mulai tahun 1980-an sampai 2003. Tahun 1980-an ditandai dengan disebutnya beberapa judul film, seperti Rambo: The First Blood Part II, Terminator, Naga Bonar, dan Dongkrak yang semuanya dirilis pada tahun 80-an. Selain judul film, buku harian milik Amak yang berjudul Agenda 1984 dan atlet bulu tangkis Icuk Sugiarto yang disebutkan dalam novel, menjadi tanda lain yang menunjukkan latar cerita dimulai pada tahun 80-an. Latar waktu 2003 disebutkan ketika Alif sudah memperoleh kesuksesan di Amerika.

Latar sosial dalam novel Negeri 5 Menara memiliki kaitan dengan latar tempat seperti Minangkabau dan Pondok Madani. Minangkabau memiliki beragam kebudayaan dan mitos seperti, budaya Marosok, tradisi pemberian nama, tradisi pemberian gelar, budaya Randai, dan kepercayaan terhadap Inyiak. Marosok merupakan budaya yang ada di daerah Minangkabau. Budaya tersebut berkaitan dengan cara pembeli dan penjual melakukan sebuah 
transaksi. Marosok dilakukan ketika membeli hewan-hewan ternak. Masyarakat Minangkabau memiliki kebiasaan unik dalam memberikan nama kepada putra-putri mereka. Kebanyakan nama-nama yang diberikan seperti nama orang Eropa, Arab, dan nama yang berasal dari singkatan. Pemberian gelar terhadap seseorang di Minangkabau terjadi ketika orang tersebut sudah menikah, karena gelar tersebut yang digunakan untuk menyebut laki-laki yang telah menikah. Gelar yang diberikan kepada orang dewasa yang telah menikah oleh masyarakat Minangkabau biasa disebut dengan istilah ketek banamo, gadang bagala, yang berarti kecil diberi nama, dewasa diberi gelar. Gelar tertinggi yang diberikan, yaitu datuk. Datuk merupakan gelar yang dihormati dan hanya dipakai oleh orang yang menjadi pemangku adat atau tokoh pemuka adat.

Randai merupakan budaya masyarakat Minangkabau, Sumatera Barat yang berupa permainan tradisional. Randai adalah kesenian dari Minangkabau yang bentuknya permainan tradisional. Pertunjukan Randai biasa dimainkan secara beregu. Dalam randai, seni musik, tari, dan silat Minangkabau dicampur menjadi satu, sehingga penampilannya mirip pagelaran teater. Sementara itu, Inyiak adalah sebutan orang Minangkabau terhadap harimau Sumatera, tetapi harimau tersebut merupakan hewan yang dapat dipelihara oleh orang sakti. Inyiak merupakan hewan legenda yang keberadaannya dipercayai oleh masyarakat Minangkabau, terutama yang hidup pada zaman dulu. Inyiak dianggap hewan yang jinak kepada orang-orang yang memiliki kekuatan tertentu. Hewan tersebut memiliki bentuk seperti harimau dan patuh terhadap orang yang memiliki kesaktian.

Dari penjelasan di atas, dapat ditarik simpulan bahwa unsur-unsur intrinsik dalam novel Negeri 5 Menara memiliki keterkaitan satu sama lain. Judul novel menggambarkan negeri impian tokoh-tokoh. Perjuangan tokoh-tokoh dalam mewujudkan cita-cita dapat diketahui melalui tema dalam cerita. Tema menjadi bagian paling komplet dalam menghubungkan unsur satu dengan lainnya. Melalui tema dapat dijelaskan proses tokohtokoh dalam mewujudkan mimpi mereka, yaitu dengan mengalami konflik-konflik dan konflik tersebut erat hubungannya dengan latar cerita, baik latar tempat, waktu, maupun sosial

\section{Analisis Sosiologi Sastra}

\section{Konteks Sosial Pengarang}

Konteks sosial pengarang berkaitan dengan posisi sosial pengarang dalam masyarakat. Melalui unsur tersebut, ditelusuri cara pengarang mendapatkan mata pencaharian, profesionalisme kepengarangan, dan masyarakat yang dituju pengarang dalam menciptakan karya (Watt dalam Damono, 1978:3-4).

Dari analisis, disimpulkan bahwa cerita yang terdapat dalam novel Negeri 5 Menara terinspirasi dari pengalaman pribadi pengarang. Tokoh Alif memiliki kemiripan dengan pengarang. Kemiripan tersebut berkaitan dengan tempat asal Ahmad Fuadi, yaitu Minangkabau. Tempat dia menempuh pendidikan, yaitu Ponorogo, dan tempat dia bekerja sebagai wartawan Tempo di Amerika.

Negeri 5 Menara merupakan salah satu novel yang dilatarbekangi oleh pengalaman pribadi pengarang. Melalui novel tersebut, Ahmad Fuadi membeberkan perjuangan hidupnya dalam memperoleh cita-cita. Ahmad Fuadi lahir di Bayur, Minanjau, Sumatera Barat pada 30 
Desember 1972. Ibunya seorang guru SD dan ayahnya bekerja sebagai guru madrasah di kampungnya. Setelah lulus SMP, ia menuruti amanat ibunya untuk bersekolah di sekolah agama. Ia memilih merantau ke Jawa dan masuk ke KMI Pondok Modern Darussalam Gontor, Ponorogo dan lulus pada tahun 1992.

Novel Negeri 5 Menara terinspirasi dari pengalaman pribadi Ahmad Fuadi. Tokoh utama dalam novel, yaitu Alif memiliki kesamaan dengan Ahmad Fuadi. Alif ingin melanjutkan SMA terbaik di Bukittinggi, tetapi terpaksa menuruti kemauan ibunya untuk bersekolah di Pondok Madani. Hal tersebut diceritakan dalam novel dengan data sebagai berikut.

"Amak, kalau memang harus sekolah agama, ambo ingin masuk pondok saja di Jawa. Tidak mau di Bukittinggi atau Padang," kataku di mulut pintu. Suara cempreng pubertasku memecah keheningan Minggu pagi itu. (Negeri 5 Menara:12)

Data di atas memperlihatkan keterpaksaan Alif ketika menuruti kemauan Amak (ibu Alif) untuk masuk ke sekolah agama. Ibunya meminta Alif untuk masuk ke sekolah agama supaya menjadi orang berguna dan berakhlak baik. Alif tidak dapat menolak dan terpaksa menuruti kemauan ibunya untuk masuk ke sekolah agama di Pondok Madani, Ponorogo, Jawa Timur.

Ahmad Fuadi memiliki bakat dalam bidang menulis, karena kebiasaan menulis buku harian dan surat kepada ibunya sewaktu sekolah di PMDG. Kebiasaan menulis buku harian ditiru dari ibunya. Hal tersebut diceritakan dalam novel Negeri 5 Menara dengan data sebagai berikut.

Selain Sahibul Menara, kawan karibku adalah diari-diariku. Aku sudah menulis diari sejak umur 12 tahun. Selama satu tahun, aku bisa menamatkan satu sampai dua buku diari. Awalnya aku melihat Amak rajin menulisi sebuah buku tebal yang kemudian aku lihat judulnya “Agenda 1984” (Negeri 5 Menara:324).

Ibu Alif berprofesi sebagai guru di kampungnya. Dia memiliki kebiasaan menulis di buku harian yang diberi nama Agenda 1984. Isi buku tersebut bermacam- macam. Mulai dari rekaman penting kehidupan, batas pelajaran yang diajarkan di sekolah, catatan pengeluaran, catatan belanja, dan petuah-petuah religius yang didapatnya ketika mengikuti acara pengajian. Kebiasaan tersebut kemudian menular kepada Alif.

Novel Negeri 5 Menara memiliki kemiripan dengan biografi Ahmad Fuadi. Melalui novel tersebut, Ahmad Fuadi berbagi kisah perjuangan bersama sahabat-sahabatnya (Sahibul Menara) dalam mewujudkan cita-cita. Dalam novel tersebut, tokoh Alif memiliki kesamaan dengan Ahmad Fuadi. Novel Negeri 5 Menara berisi kisah sehari-hari kehidupan santri di PMDG. Penyajian fakta yang ditulis oleh Ahmad Fuadi dalam novel cukup menarik, karena kemodernan sistem pendidikan di PMDG ditonjolkan. Melalui novel tersebut, Ahmad Fuadi menerangkan bahwa pesantren sudah tidak kolot dan sudah mampu menyaingi pendidikan pada umumnya. Negeri 5 Menara memiliki kekhasan ide cerita yang membuatnya masuk dalam kategori best seller. 
Selain berkaitan dengan latar belakang pengarang, peneliti juga menyimpulkan bahwa Ahmad Fuadi memiliki profesionalisme terhadap dunia kepengarangan. Dia memilih untuk fokus berkarir sebagai pengarang dan berhenti menjadi wartawan.

\section{Sastra sebagai Cerminan Masyarakat}

Sastra sebagai cerminan masyarakat, berhubungan dengan kedudukan sastra yang dianggap tiruan dari kenyataan dalam masyarakat. Unsur tersebut menelusuri hal yang berkaitan dengan sastra yang mencerminkan peristiwa pada masa tertentu, pemilihan faktafakta masyarakat yang ingin ditonjolkan oleh pengarang, genre sastra, dan usaha karya sastra dalam menampilkan keadaan masyarakat secermat-cermatnya (Watt dalam Damono, 1978:3-4).

Sastra sebagai cerminan masyarakat merupakan pokok pembahasan dalam novel Negeri 5 Menara yang berkaitan dengan modernisasi pendidikan pesantren. Novel Negeri 5 Menara merupakan karangan pertama Ahmad Fuadi. Melalui novel tersebut, dia menceritakan kisah tentang kehidupannya ketika sekolah di Pondok Modern Darussalam Gontor. Kemodernan sistem pendidikan yang diterapkan di PMDG menjadi salah satu faktor ketertarikan masyarakat untuk membaca novel tersebut. Dalam novel Negeri 5 Menara, Ahmad Fuadi menggambarkan PMDG sebagai Pondok Madani. Pondok Madani menjadi tempat tokoh-tokoh dalam novel belajar hingga akhirnya berhasil sukses berkat usaha dan kerja keras mereka. Kesuksesan mereka tidak lepas dari cara Pondok Madani mendidik santrisantrinya selama enam tahun. Sistem pendidikan yang religius, disiplin, dan ketat berhasil membuat mereka menjadi orang-orang yang mampu bersaing di dunia internasional. Adapun penggambaran fakta-fakta sosial yang diangkat dalam novel Negeri 5 Menara dan berkaitan dengan kemodernan sistem pendidikan di pesantren, yaitu jasus (mata-mata), kedisiplinan waktu, cara berpakaian, muhadharah (pidato dengan tiga bahasa), hapalan kosakata, penggunaan bahasa asing, sistem penerimaan santri dengan seleksi, dan kegiatan ekstrakurikuler. Pondok Modern Darussalam Gontor memiliki cara mendidik yang khas dan disiplin. Hal tersebut digambarkan di Pondok Madani yang terdapat dalam novel Negeri 5 Menara. Di pesantren tersebut, santri-santri dituntut untuk disiplin dan bagi mereka yang melanggar, maka akan dikenai sanksi, yaitu menjadi jasus.

Jasus adalah bahasa Arab yang berarti mata-mata. Spion. Seperti Roger Moore, Agent 007, yang menyaru dan diam-diam menyelusup ke sarang musuh untuk mengumpulkan informasi rahasia. Entah bagaimana caranya, PM dengan cerdik menemukan sebuah metode unik yang mengawinkan dua metode yang terpisah jauh: kepiawaian spionase Roger Moore dan disiplin pondok. Tujuannya untuk menegakkan hukum dan disiplin. (Negeri 5 Menara:76).

Jasus merupakan bentuk sanksi yang diterima oleh santri-santri yang melanggar peraturan. Santri-santri yang menjadi jasus merupakan santri yang melanggar aturan kedisiplinan, seperti datang terlambat, menggunakan bahasa daerah pada hari bahasa asing, dan sebagainya. Mereka yang melanggar diumumkan namanya ketika selesai salat Magrib. 
Mereka harus pergi ke kantor keamanan pesantren untuk mendapat hukuman, yaitu menjadi jasus.

Selain ketat dalam pembagian waktu belajar dan pemberian sanksi, Pondok Madani juga ketat dalam mendisiplinkan santri-santrinya dalam berpakaian. Dalam novel Negeri 5 Menara, Ahmad Fuadi secara tidak langsung menyebutkan bahwa salah satu hal yang membedakan antara PMDG dengan pesantren lainnya, yaitu cara berpakaian santrinya. Jika santri di pesantren pada umumnya memakai sarung, justru di PMDG sarung hanya digunakan ketika melaksanakan salat atau tidur. Dalam kegiatan sehari-hari, para santri lebih sering memakai kemeja dan celana panjang ketika melakukan kegiatan sehari-hari.

Sistem pendidikan PMDG yang modern juga dapat dilihat dari kegiatan tambahan yang diselenggarakan di sana, yaitu kegiatan muhadharah atau latihan pidato. Kegiatan ini bukan latihan pidato seperti pada umumnya, pidato yang dihapalkan harus menggunakan tiga bahasa, yaitu bahasa Arab, bahasa Inggris, dan bahasa Indonesia. Dalam novel Negeri 5 Menara, hal tersebut dapat dilihat dari data berikut.

Menurutku bila ingin mendapat pelatihan hebat untuk menjadi orator tangguh dan singga podium, maka PM adalah tempat yang tepat. Bagaimana tidak, tiga kali seminggu, selama 2 jam kami diwajibkan mengikuti muhadharah, atau latihan berpidato di depan umum. Setiap orang mempunyai kelompok pidato berisi 40 anakanak dari kelas lain. Setiap orang dapat giliran berbicara 5 menit di depan umum. Tidak hanya harus berpidato tanpa teks, bahkan tingkat kesulitannya ditingkatkan dengan kewajiban harus berpidato dalam 3 bahasa, Indonesia, Inggris, dan Arab. (Negeri 5 Menara:149).

Kemoderenan sistem pendidikan di PMDG dapat dilihat dari kemampuan santrisantrinya yang fasih dalam menggunakan bahasa asing seperti bahasa Arab dan bahasa Inggris. Kedua bahasa tersebut merupakan bahasa yang wajib digunakan di PMDG selama 24 jam. Dalam novel Negeri 5 Menara, Ahmad Fuadi menjelaskan bahwa santri di Pondok Madani wajib berbicara menggunakan bahasa Arab dan Inggris setelah melewati empat bulan tinggal di pesantren. Dalam novel Negeri 5 Menara, kemodernan sistem pendidikan pesantren juga diperlihatkan dari cara Pondok Madani menerima murid baru, yaitu dengan sistem seleksi. Kemodernan lainnya yang ditampilkan dalam novel Negeri 5 Menara, yaitu adanya kegiatan ekstakurikuler yang dapat diikuti oleh seluruh santri Pondok Madani untuk mengasah minat dan bakat. Jenis ekstakurikuler yang disediakan ada begaram, bahkan dapat dikatakan tidak kalah dari sekolah-sekolah umum.

Paparan tersebut menunjukkan bahwa Pondok Madani sebagai cerminan dari PMDG menerapkan sistem pendidikan modern dalam mendidik santri. Kemodernan tersebut meliputi, jasus (mata-mata), penerapan kedisiplinan waktu, kedisiplinan berpakaian, mudhaharah (pidato menggunakan tiga bahasa), hapalan kosakata Arab, peggunaan bahasa asing (Arab dan Inggris), sistem penerimaan dengan seleksi, dan kegiatan ekstrakurikuler. 


\section{Fungsi Sosial Sastra}

Fungsi sosial sastra berkaitan dengan efek karya sastra pada tataran penikmat (pembaca). Dalam unsur tersebut dibahas fungsi-fungsi karya sastra, yaitu tentang kedudukan sastra yang dikatakan harus menjadi pembaru dan perombak, sastra sebagai karya yang berfungsi untuk memberi hiburan belaka, dan sastra yang memberikan amanat-amanat tertentu dengan cara menghibur (Watt dalam Damono, 1978:3-4).

Dalam fungsi sosial sastra, peneliti mengumpulkan dan memilah data dari beberapa sumber melalui internet. Beragam respons dimunculkan dalam menilai amanat dan manfaat setelah membaca novel Negeri 5 Menara. Pembaca memperoleh informasi, dan pengetahuan dari novel tersebut.

Terciptanya sebuah karya sastra dilatarbelakangi oleh kondisi masyarakat yang melingkupi kehidupan pengarang. Seorang pengarang memiliki kepekaan terhadap persoalan sosial di lingkungannya. Ia memiliki wawasan yang mendalam tentang kehidupan sosial masyarakat. dan mencoba untuk menciptakan tiruan kehidupan masyarakat dalam bentuk karya sastra. Ahmad Fuadi sebagai pengarang novel Negeri 5 Menara, ingin menciptakan novel yang dapat memperluas pemikiran dan informasi yang mampu memberikan manfaat kepada pembacanya. Ahmad Fuadi memaparkan tujuannya menulis karya sastra, yaitu untuk menebar kebaikan. Dia percaya bahwa tulisan dapat memberikan inspirasi bagi banyak orang. Tulisan yang baik tidak hanya membuat kagum pembaca, tetapi juga memiliki kekuatan untuk membuat pembaca ingin melakukan sesuatu, dan merasa bersalah jika tidak melakukannya.

Karya sastra bukan hanya sebagai alat untuk menghibur pembaca. Dalam sebuah karya terdapat beragam pengalaman, ide-ide, pengetahuan, motivasi, dan informasi positif yang dibagikan oleh pengarang. Semakin berkualitas karya sastra, semakin kekal karya tersebut untuk dibaca oleh setiap generasi. Ahmad Fuadi meyakini bahwa manfaat sebuah karya sastra yang baik akan terus menyebar, bukan hanya pada generasi ketika karya tersebut terbit, melainkan juga pada generasi selanjutnya.

Dalam novel Negeri 5 Menara, Ahmad Fuadi menceritakan tentang pesantren yang telah memiliki sistem pendidikan yang modern. Masyarakat umumnya menilai pesantren hanya sebagai lembaga pendidikan agama, dan alumni pesantren hanya dapat menjadi seorang ustaz. Pandangan tersebut dapat berubah ketika telah selesai membaca novel Negeri 5 Menara. Masyarakat akan memperoleh informasi baru, bahwa sekarang pesantren sudah tidak lagi kolot. Sudah ada pesantren yang memperbarui sistem pendidikan menjadi lebih modern, sehingga kualitas alumninya mampu bersaing di dunia internasional. Melalui novel tersebut, Ahmad Fuadi memperkenalkan Pondok Madani sebagai salah satu pesantren modern yang patut dipertimbangkan oleh anak-anak dan orang tua dalam memilih lembaga pendidikan. Tulisan Ahmad Fuadi mampu merombak pemikiran kolot masyarakat tentang pesantren yang awalnya dianggap ketinggalan zaman.

Tulisan yang baik membuat minat baca masyarakat meningkat. Pembaca merupakan orang yang berpengaruh dalam penilaian sebuah karya sastra. Pembaca menentukan segi positif dan negatif dari sebuah karya sasta. Pembaca dapat berasal dari berbagai kalangan, baik dari anak-anak, remaja, maupun orang dewasa. Pembaca tidak hanya berasal dari orangorang berpendidikan, seperti pelajar, mahasiswa, guru, dosen, dan sebagainya, tetapi juga 
dapat berasal dari segala golongan. Karya sastra yang baik mampu dinikmati oleh setiap golongan pembaca, karena penulisannya mudah untuk dipahami. Novel Negeri 5 Menara karya Ahmad Fuadi merupakan salah satu contoh novel yang dapat dibaca oleh semua kalangan. Tema pendidikan yang diambil, mampu memberikan manfaat bagi pelajar, mahasiswa, dan orang tua. Berikut data review pembaca tentang novel Negeri 5 Menara yang diperoleh dari Goodreads.

Buku ini jelas mampu merobohkan stigma buruk apapun yang ada di dalam kepala saya tentang kehidupan pesantren. Jorok, kotor, bau, tampaknya tidak terbukti di sini. Dengan rasa tertampar malu, serta dengan segala kerendahan hati, saya pun mengakui pernah khilaf memandang sebelah mata kepada kualitas para 'lulusan pesantren'. Tapi kemudian, semua pandangan berubah, ketika saya masuk dunia perkuliahan. (https://www.goodreads.com).

Salah satu pembaca di Goodreads dengan username Ataventis mengungkapkan keberhasilan novel Negeri 5 Menara dalam mengubah pemikirannya tentang pesantren. Sebagai orang yang terbiasa hidup di Jakarta, ia mengaku bahwa menempuh bidang pendidikan di pesantren bukan menjadi pilihan utamanya. Sebelum membaca novel Negeri 5 Menara, ia berpikir bahwa lingkungan pesantren tidak bersih dan kualitas alumni pesantren tidak sebanding dengan kualitas pendidikan sekolah umum. Pemikiran negatif tersebut menjadi keliru ketika ia telah membaca novel Negeri 5 Menara. Di dalam novel tersebut, ia tidak menemukan kebiasaan santri yang buruk dalam mengelola lingkungan pesantren. Justru, pesantren menjadi lembaga pendidikan agama yang bermutu, baik dalam mendidik siswa maupun dalam membina akhlak. Ahmad Fuadi berhasil memberikan informasi, serta meluruskan kekeliruan pembaca dalam menilai kualitas pesantren.

Stigma buruk tentang pesantren dalam pandangan masyarakat mulai hilang. Novel Negeri 5 Menara membuat pembaca mengetahui bahwa kehidupan pesantren tidak lagi kolot dan kotor. Dalam bidang pendidikan, pesantren mulai memajukan kualitasnya, sehingga dapat bersaing dengan sekolah umum. Hal tersebut membuat pembaca terinspirasi dan menjadikan pesantren sebagai bahan pertimbangan untuk mendaftar sekolah.

Di Indonesia, novel Negeri 5 Menara sudah menjadi bacaan wajib di berbagai sekolah diantaranya, yaitu di SMA Santa Ursula, SMA High Scope, dan SMA Bina Nusantara, Jakarta. Tidak hanya menjadi bacaan wajib, novel Negeri 5 Menara juga menjadi bahan kajian yang dibahas dalam skripsi dan tesis mahasiswa. Ahmad Fuadi bangga setelah mengetahui banyak lembaga pendidikan, baik dalam negeri maupun luar negeri yang membahas novel Negeri 5 Menara. Ia senang karena novelnya dapat dibahas secara ilmiah, dan menjadi suatu bahan kajian di sekolah dan universitas. Hal tersebut membuktikan bahwa tulisannya telah berhasil menggeretak pembaca, dan melalui tulisan tersebut, ia telah menjadi sosok yang dapat memberi manfaat kepada orang lain. Pada dasarnya, fungsi sosial sastra merupakan hubungan antara suatu karya sastra dengan masyarakat pembaca. Setiap pengarang yang menciptakan sebuah karya sastra, juga akan memberikan amanat untuk pembaca. Novel Negeri 5 Menara mempunyai dampak sosial bagi pembaca, yaitu memberikan manfaat, pengetahuan, inspirasi, dan motivasi tentang hal yang berkaitan dengan 
Modernisasi Pendidikan: Potret Dinamika Sosial Pendidikan Pesantren dalam Novel Negeri 5 Menara Karya Ahmad Fuadi (Naeli Wardani, Heru S.P. Saputra, Sunarti Mustamar)

pendidikan pesantren. Novel tersebut memberikan informasi positif kepada kaum pelajar dan orang tua tentang kemodernan sistem pendidikan pesantren yang sekarang sudah berkembang.

\section{SIMPULAN}

Berdasarkan hasil pembahasan, unsur-unsur struktural seperti, judul, tema, tokoh, konflik, dan latar memiliki hubungan yang saling berkaitan. Pemaknaan terhadap judul Negeri 5 Menara berkaitan dengan cita-cita tokoh. Perjuangan tokoh dalam mewujudkan cita-cita diketahui dari tema yang dimunculkan dalam cerita. Tema cerita merangkum proses dan kejadian yang dialami tokoh. Kehidupan tokoh utama tidak akan mengalami perubahan jika tidak diimbangi oleh adanya tokoh-tokoh yang lain. Hubungan tersebut memunculkan konflik yang terjadi dalam cerita. Permasalah yang dialami tidak lepas kaitannya dengan latar dalam cerita, baik itu latar waktu, latar tempat, maupun latar sosial yang melatarbelakanginya.

Kajian sosiologi sastra yang digunakan dalam meneliti novel Negeri 5 Menara mencakup tiga hal, yaitu konteks sosial pengarang, sastra sebagai cerminan masyarakat, dan fungsi sosial sastra. Dalam konteks sosial pengarang, peneliti menyimpulkan bahwa novel Negeri 5 Menara terinspirasi dari biografi pengarang. Perpindahan profesi dari jurnalis menjadi penulis merupakan bentuk profesionalisme pengarang untuk berkarir dalam bidang sastra. Sastra sebagai cerminan masyarakat diperlihatkan dari sistem pendidikan di Pondok Madani yang memiliki kemiripan dengan PMDG, seperti jasus, penerapan kedisiplinan waktu, kedisiplinan berpakaian, mudhaharah (pidato menggunakan tiga bahasa), hapalan kosakata Arab, peggunaan bahasa asing (Arab dan Inggris), sistem penerimaan dengan seleksi, dan kegiatan ekstrakurikuler.

Dalam fungsi sosial sastra, novel Negeri 5 Menara termasuk novel yang dapat dinikmati oleh berbagai kalangan. Keberagaman tersebut memunculkan tanggapan-tanggapan yang berbeda dari setiap pembaca. Ada yang menikmati novel sebagai sebuah karya seni, hiburan, dan penelitian, tetapi secara garis besar, setelah membaca novel Negeri 5 Menara, banyak yang menerima pengetahuan baru dalam memperbaiki stigma tentang kehidupan pesantren.

\section{DAFTAR PUSTAKA}

Damono, S. D. 1978. Sosiologi Sastra: Sebuah Pengantar Ringkas. Jakarta: Pusat Pembinaan dan Pengembangan Bahasa, Departemen Pendidikan dan Kebudayaan.

Escarpit, R. 2005. Sosiologi Sastra. Jakarta: Obor.

Faruk. 2015. Pengantar Sosiologi Sastra. Yogyakarta: Pustaka Pelajar.

Fuadi, A. 2009. Negeri 5 Menara. Jakarta: Gramedia.

Junus, U. 1986. Sosiologi Sastera: Persoalan Teori dan Metode. Kuala Lumpur: Dewan Bahasa dan Pustaka.

Maslikatin, T. 2007. Kajian Sastra: Prosa, Puisi, Drama. Jember: UNEJ Press.

Nurgiyantoro, B. 2005. Teori Pengkajian Fiksi. Yogyakarta: Gadjah Mada University Press.

Ratna, N.K. 2004. Teori, Metode, dan Teknik Penelitian Sastra dari Strukturalisme hingga Postrukturalisme: Perspektif Wacana Naratif. Yogyakarta: Pustaka Pelajar.

Saraswati, E. 2003. Sosiologi Sastra: Sebuah Pemahaman Awal. Malang: Bayu Media \& UMM Press. 
Semi, M. A. 1990. Metode Penelitian Sastra. Bandung: Angkasa.

Suharto, B. 2018. Pondok Pesantren dan Perubahan Sosial: Studi Transformasi Kepemimpinan Kiai Pesantren. Yogyakarta: Pustaka Ilmu.

Wellek, R. dan Warren. A. 2014. Teori Kesusastraan. Terjemahan Budianta, M. Jakarta: Gramedia Pustaka Utama. 